\title{
English Vocabulary Learning Application For Students of SD Negeri Cibatu, Tasikmalaya Regency
}

Laura

Jurusan Teknik Informatik, Fakultas Teknik, Universitas Citra Buana Indonesia

\section{Article Info}

Article history:

Received: $22 / 04 / 2021$

Revised: 06/05/2021

Accepted: 28/05/2021

Available online30/06/2021

\section{Keywords:}

Application;

English;

Vocabulary,

\begin{abstract}
Teaching that seems conventional can cause students to find it difficult to understand the material presented by the teacher, as a result, student interest in learning will result in a decrease and have an impact on student achievement. Starting from this, learning by using multimedia that uses media elements such as animation, text, and images that are packaged in a container that is interactive, creative, and fun in order to attract students to increase student interest in learning. Based on the aforementioned background, the purpose and benefit of this research is to build an application for learning English vocabulary for elementary school students in grades 1, 2 and 3 using macromedia flash. It is hoped that this learning application can be used as an application that helps teachers in the learning process,
\end{abstract}

This is an open access article under theCC BY-NClicense.

Corresponding Author:

Laura,

Jurusan Teknik Informatika,

Fakultas Teknik, Universitas Citra Buana Indonesia

Email: lauara08@gmail.com

\section{Introduction}

English lessons are subjects that are prioritized for elementary level students. English lessons are needed in welcoming the era of globalization. English lessons are new lessons for elementary school students in grades 1, 2 and 3 (Febriyanti, 2018) (Fattah, Hartati, \& Mulyasari, 2009). Because this lesson is a new lesson learned, elementary school students in grades 1, 2 and 3, often have difficulty learning it

English lessons are very much packaged in the form of books. The presentation in the book also varies, some use only writing and some only use pictures and writing (Indriastuti, 2020) (Soedarso, 2014). For psychologically children who tend to prefer to play rather than study, reading is one of the difficulties in learning from books. Therefore, it can be said that the English lessons given by books are not of interest to students (Ariantoro, 2016) (Nugrahani, 2007).

The last problem that arises is that the material presented by the book is less interactive. To build student interest, situations that are more interactive than books are needed. So far, the material presented by the book only educates students to read and write in a learning situation, not in a play situation. Therefore, a situation that is more directing students such as playing is needed so that students can be more interactive in learning activities (Nuritno \& Raharjo, 2017) (Noviyanthi, Sadyana, \& Adnyani, n.d.).

\section{Method}

\subsection{Method of collecting data}

Data collection methods used in this study are as follows: 
a. Literature review

Collecting data by collecting readings that are related to the research title.

b. Observation Method is a way of collecting data through observation, recording of symptoms that occur directly at the research site.

c. Interview Method

Data collection techniques by holding direct questions and answers about things that have to do with the topic taken.

\subsection{Application Development Method}

In building this learning application, the Waterfall software development method is used which includes:

a. Analysis

Analysis is the stage of analyzing the things needed in the implementation of application development.

b. Design

The design stage is the translation stage of the analyzed data into a form that is easily understood by users.

c. $\quad$ Coding

The stage of data translation or problem solving that has been designed into a particular programming language.

d. Test

This stage is the testing stage of the application that was built.

e. Maintenance

The final stage where an application that has been completed can undergo changes or additions according to user requests.

\section{Results and Discussion}

\subsection{System Implementation}

\section{a. Execution File Creation}

An executable file is a program file that has been translated into machine language. This executable file is run from outside the application that created it, and usually has an .EXE extension. The purpose of making this extension file is so that users can directly call the application without having to run Macromedia Flash first. So that users who do not install Macromedia Flash on their computers can use this application. The following are the steps for creating an executable file for the English Introduction Application:

1). From the File menu, select Publish Settings

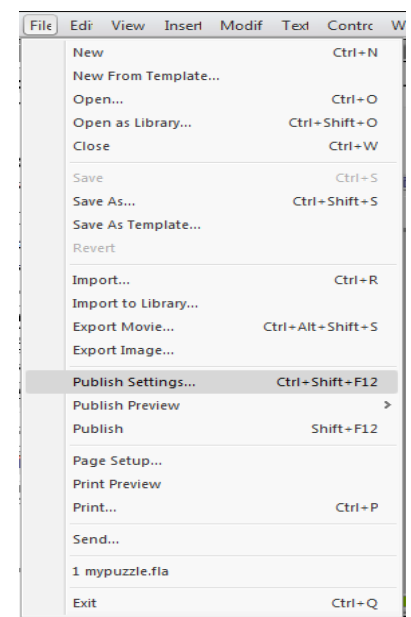

Figure 1. File Menu Display and Selection of Publish Settings 
2). After the Publish Settings window appears, select the Formats tab. Uncheck the HTML checkbox (.html), replace it by clicking the Flash (.swf) and Windows Projector (.exe) checkboxes.

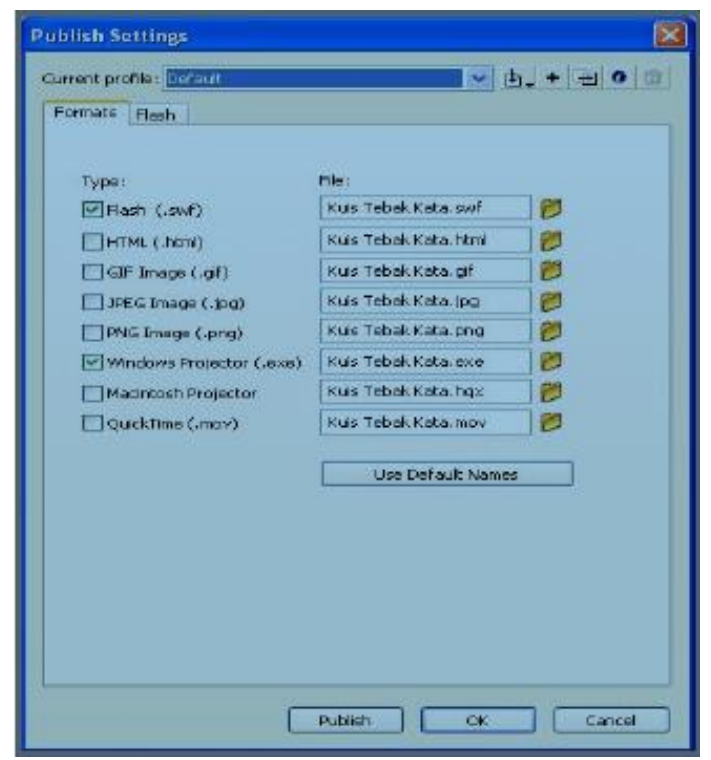

Figure 2Publish Settings window

3). Select the Publish button to create an executable file. The file will be published as an exe extension.

4). After the publish process is complete, select OK to close the Publish Settings dialog box

5). After publishing the flash file, a new file of type (.exe) will appear.

\section{b. Running the program}

To run this application, users do not have to do any installation process. Because this application is made to be easy to use and carry anywhere. Users can directly run this application from the storage media used. For example, run directly from the flash, or CD. The steps taken to run this multimedia application is to click the icon for the English Introduction Application.exe file.

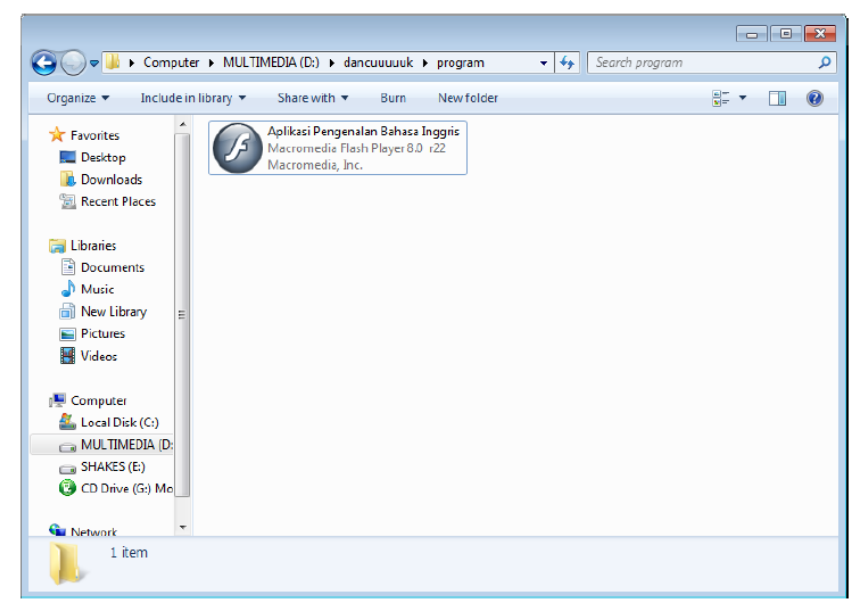

Figure 3. Selecting the English Recognition Application File.exe 
The results of system planning cannot be implemented before the existence of a physical system, namely technological components in the form of hardware and software. Hardware technology consists of input devices, processing devices, output devices and external storage media. Meanwhile, software technology is used to support hardware. Software instructions are written by humans to activate the functionality of the hardware.

\section{Conclusion}

Based on the results of making this multimedia application, several conclusions can be drawn such as the use of this application in learning English is very useful because it can cover the shortcomings of other learning media such as books that can not speak and are not attractive. By utilizing technology, especially multimedia, this application provides information about English by displaying text, sound and images, and can interact directly in the learning process, and can increase children's motivation to learn English. the end of the program in the form of an attractive appearance and easy to use the user.

\section{Reference}

Ariantoro, T. R. (2016). Dampak Game Online Terhadap Prestasi Belajar Pelajar. JUTIM (Jurnal Teknik Informatika Musirawas), 1(1).

Fattah, N., Hartati, T., \& Mulyasari, E. (2009). Manajemen Sekolah Bertaraf Internasional. Jurnal Educationist, 3(1), 19-31.

Febriyanti, E. R. (2018). Identifikasi analisis kebutuhan pembelajar bahasa inggris (non program studi bahasa Inggris) pada mata kuliah bahasa Inggris ESP di lingkungan FKIP Universitas Lambung Mangkurat Banjarmasin. Vidya Karya, 32(2), 123-138.

Indriastuti, N. R. (2020). KECUKUPAN BUKU TEKS "WHEN ENGLISH RINGS A BELL" DALAM MEMEUNUHI KOMPETENSI DASAR BAHASA INGGRIS DI SMPN1 PONOROGO. Jurnal Dimensi Pendidikan Dan Pembelajaran, 8(2), 64-71.

Noviyanthi, N. N. P., Sadyana, I. W., \& Adnyani, K. E. K. (n.d.). PEMBELAJARAN KANJI DI KELAS N4 KEPERAWATAN LPK LPJ (Lembaga Pelatihan Bahasa Jepang) BALI.

Nugrahani, R. (2007). Media pembelajaran berbasis visual berbentuk permainan ular tangga untuk meningkatkan kualitas belajar mengajar di sekolah dasar. Lembaran Ilmu Kependidikan, 36(1).

Nuritno, R., \& Raharjo, H. (2017). Pengembangan Bahan Ajar Berbasis Multimedia Interaktif Dalam Meningkatkan Minat Belajar Matematika Siswa. ITEj (Information Technology Engineering Journals), 2(1), 1-10.

Soedarso, N. (2014). Perancangan Buku Ilustrasi Perjalanan Mahapatih Gajah Mada. Humaniora, 5(2), 561-570. 